Metaphoric Blends in Online Cartoons on Egypt's Education System

\author{
Dr. Abeer El Attar \\ Lecturer - Department of English
}

Faculty of Al- Alsun, Ain Shams University

د. عبير العطار

مدرس بقسم اللغة الإنجليزية

كلية الآداب - جامعة حلو الان ل 



\section{Metaphoric Blends in Online Cartoons on Egypt's Education System}

\section{Abstract}

Political cartoons, as a visual medium, abound in metaphor for its powerful impact on viewers/readers; they comment on various social, cultural, and political aspects of life. On that account, this paper is meant to explore metaphor from the cognitive perspective of conceptual blending theory- developed by Fauconnier and Turner (2002) - in five online cartoons by Dr. Sherif Arafa. The theory presents a framework for online meaning construction via mappings, selective projections and other conceptual blending processes to yield novel dynamic inferences. The paper addresses metaphoric blends, as specified by Grady (2005), in an attempt to uncover the cognitive processes pertaining to meaning construction and the ideological assumptions underpinning such metaphoric cartoons. The five cartoons focus on Egypt's education system. The study concludes that double-scope integration networks dominate the five cartoons; moreover, metaphoric blends are triggered via experiential correlations and analogical mappings. The cartoonist criticizes the current education strategies in Egypt via his ideologically loaded cartoons.

Keywords: conceptual integration network, conceptual blending, metaphoric blends, political cartoons, education system, meaning construction

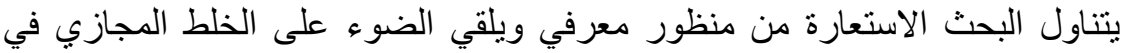

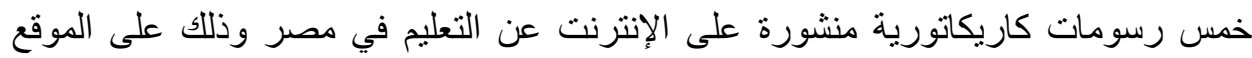

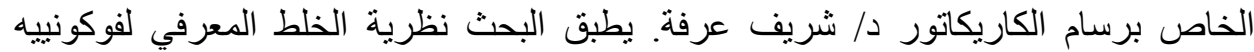

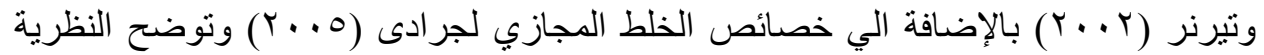

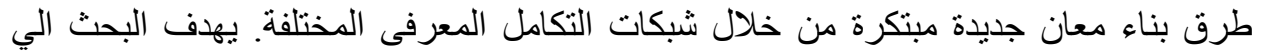

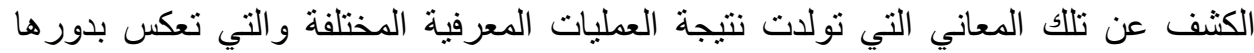

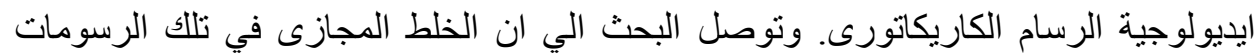

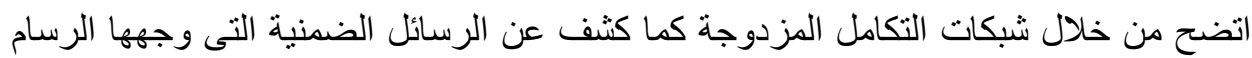

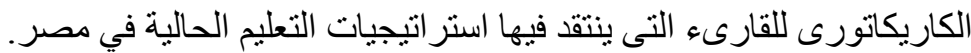




\section{Metaphoric Blends in Online Cartoons on Egypt's Education System}

\section{Introduction}

Metaphor, a major type of figurative language loaded with expressive meaning, grabs attention, conjures up images, and conveys new concepts (Croft \& Cruise, 2004, p.193). It is not only a ubiquitous linguistic phenomenon but a conceptual process grounded in thought and human experience. Consequently, it has been a preoccupation of cognitive linguistics, especially cognitive semantics. One of the influential theories that accounts for metaphor is Fauconnier and Turner's (1998, 2002) Conceptual Integration Theory, where metaphor, a subset of conceptual integration, underlies the blending processes. Blending, an intrinsic cognitive process, plays a role in the construal of abstract concepts such as education. Hence, this paper examines the meaning constructed via metaphoric blending in the selected cartoons on education. Cartoons activate visual conceptual blending (Croft \&Cruise, 2004; Fludernik, 2015). To that end, the paper addresses Grady's (2005) specifying features of metaphoric blends. Hart (2016) stresses the role of metaphor in representing "ideology in discourse" (p.143); thus, the study aims at unraveling the cartoonist's stance. The theory serves in visualizing the organization of the selected cartoons.

\subsection{Aim of Study}

The study attempts to account for instantiating conceptual metaphoric bends in online cartoons that portray the education system in Egypt. The study also attempts to uncover ideological implications and convey the cartoonist's subtle messages via the conceptual blending model. In this respect, the study addresses the following questions:

1. What type of network is employed in each of the five cartoons? How are these networks constructed?

2. How do the verbal and/or the visual modes of the cartoon contribute to the cognitive process of meaning construction?

3. In what way does each cartoon activate a metaphoric blend?

4. What inferences does the cartoonist intend to generate?

5. How do such metaphoric blends reflect the ideological thrust of the cartoonist? 


\section{Review of Literature}

Conceptual blending theory has gained considerable attention from some researchers, who applied the framework to political cartoons, advertisements, jokes, political speeches, English proverbs, internet catchwords, and radio talk shows. Abdel-Raheem (2016) adopts Fauconnier and Turner's (1998) conceptual blending theory to analyze a political cartoon by Mostafa Houssien against the Muslim Brotherhood. The analysis is supported by a crowdsourcing experiment to examine the impact of this cartoon on the people's political attitudes. Results show that political cartoons can affect political attitudes. In another study, Coulson (2005) applies Fauconnier and Turner's (2002) conceptual integration on a radio call-in show. The study accounts for the process of meaning construction in humorous conversational interactions between two hosts, a physician and a comedian, from a radio talk show. Coulson concludes that blending proved useful in accessing conversational jokes and the conversational context affects the humorous conceptualizations triggered by blending.

Džanić and Omazić (2011) draw upon Fauconnier and Turner's (2002) conceptual integration theory to account for the meaning construction in selected cartoons discussing the political and economic status in Bosnia, Herzegovina, and the United States. The study explains the humorous effect of a clash between two contrasting scenarios, which is characteristic of humorous blends. Joy, Sherry, and Deschenes (2009) adopt Fauconnier and Turner's (2002) conceptual blending framework to examine three advertisements representing three different types of networks in order to analyze the cognitive processes that consumers use to construct meaning. They interviewed 28 participants (i.e., consumers) to account for the ways they interpret such ads. They conclude that the visual representations trigger blends in creative ways. Moreover, they add that mingling the textual and visual materials trigger an emotional response.

Kok and Bublitz (2011) apply Fauconnier and Turner's (2002) conceptual blending framework to a political joke and an extract of a political speech and examine the role of blending in understanding the concepts of evaluation (i.e., the speaker's/writer's attitude) and common 
ground (i.e., shared conceptual and semantic knowledge) in the two texts. They regard evaluation as a mental process, not as a textual phenomenon that involves mappings, and other cognitive skills. They conclude that blending helped in the construal of texts with implicit evaluative meanings and establishment of common ground.

Li and Gao (2011) adopt Fauconnier and Turner's (2002) conceptual blending framework to analyse three internet catchwords in 2010, the widely used online phrases, in addition to three other utterances. The study attempts to account for the meaning construction process of these catchwords and utterances in order to shed light upon the trend of people's taste. They conclude that blending serves in dynamic meaning construction and provides a deeper understanding of such catchwords from a cognitive perspective. In a different application, Yongxiang (2015) adopts Fauconnier and Turner's (2002) conceptual integration framework to account for meaning construction and cognitive processes underlying English proverb construal. The study concludes that conceptual blending reveals how people interpret English proverbs from a cognitive perspective.

In an attempt to fill in a certain gap in previous studies, this paper addresses metaphoric blends in cartoons from a cognitive perspective, adopting Fauconnier and Turner's (2002) framework of conceptual blending and Grady's (2005) specifying features of metaphoric blends.

\section{Theoretical Background}

\subsection{Conceptual Integration Theory}

The present study provides a brief - yet comprehensive-outline of Gilles Fauconnier and Mark Turner's (2002) Conceptual Blending Theory (CB), which is also known as Conceptual Integration Theory, theory of online meaning construction, or the network theory (Coulson \& Oakley, 2000). CB is based on Conceptual Metaphor Theory (CMT), in terms of mappings and projections, and Mental Spaces Theory (MST) in terms of mental spaces to account for the construction of meanings (Evans \& Green, 2006). Conceptual Integration Theory is a basic mental activity embedded in every aspect of human experience (Coulson \& Oakley, 2000; Evans \& Green, 2006; Fauconnier \& Turner, 2002; Turner, 2006). Coulson and Oakley (2000) claim that "Conceptual blending is a 
theoretical framework for exploring human information integration" (p.176). CB focuses on language, thought and imagination (Coulson \& Oakley, 2000; Evans\& Green, 2006; Fauconnier \& Turner, 2002). Consequently, Fauconnier and Turner (2002) and Coulson (2006) claim that blending triggers novel concepts as it depends on the reader's imagination.

According to Fauconnier and Turner (2002), the role of conceptual blending involves the construction and integration of mental spaces. They define mental spaces as "small conceptual packets constructed as we think and talk, for purposes of local understanding and action" (p.40). They assert that the mental spaces contain elements and relations. The elements, as Coulson (2006) claims, "represent each of the discourse entities", and "the relationships that exist between them" (p.189) are structured by frames. Hart (2016) adds that frames are "the richer knowledge bases" triggered by elements in discourse (p.138), and that activating one feature of a frame triggers all the other features.

Fauconnier and Turner (2002) assume that "Mental spaces can be used generally to model dynamic mappings in thought and language" (p.40). Coulson (2005) defines mappings as "abstract correspondence between elements or relations in different mental spaces" (p.108). Fauconnier and Turner (2002) maintain that such mappings established between counterpart elements are known as outer-space vital relations, and can be based on relations of time, space, identity, representation, change, role-value, analogy, disanalogy, part-whole, cause-effect. They add metaphoric connections and "connections between frames and roles in frames" (p.47). These relations are, as Evans and Green (2006) claim, compressed in the blend into inner-space relations. Fauconnier and Turner (2002) stress that compression is an advantage of CB because it offers "compressions to human scale of diffuse arrays of events" (p.30).

In short, mental spaces, mappings, vital relations, compression, in addition to other features of conceptual blending are incorporated in the network model of conceptual integration. Fauconnier and Turner (2002) maintain that conceptual blending is structured in terms of integration networks whose most basic form is presented in the next section. 


\subsection{The Structure of the Integration Network}

Figure1 below illustrates the main features of conceptual integration network, which Grady, Oakley, and Coulson (2007/1999) call the "four-space model", as it is composed of, at least two input spaces, one generic space, and one blended space.

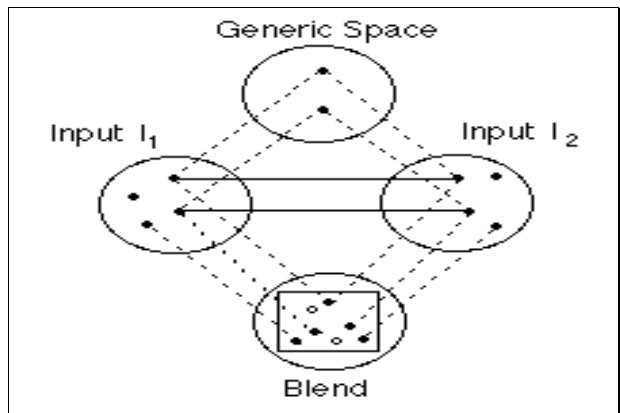

\section{Figure 1. The Basic Diagram of the Integration Network} (Fauconnier\& Turner, 2002, p.46)

The input spaces incorporate elements and relations; the counterpart elements in the two input spaces are connected by cross-space mappings (Fauconnier \& Turner, 2002). The generic space incorporates the common characteristics that the inputs share and maps onto each input space. It motivates mapping (matching) between counterparts across input spaces (Evans \& Green, 2006; Fauconnier \& Turner, 1998; 2002). Selected elements from the input spaces are projected to the blend, which in turn integrates them and dynamically develops the novel emergent structure (Evans\& Green, 2006). The emergent structure is derived via three basic imaginative blending processes: composition, completion, and elaboration, respectively (Coulson \& Oakley, 2000; Grady et al., 2007/1999; Fauconnier\& Turner, 1998; 2002).

Composition provides new relations between elements projected from the input spaces to the blend; such relations were not available in the separate inputs (Coulson \& Oakley, 2000; Fauconnier \& Turner, 1998, 2002). Counterpart elements can be fused in the blend or brought as separate entities (Fauconnier \& Turner, 1998, 2002). Completion pertains to recruiting background knowledge unconsciously to the blend (Coulson \& Oakley, 2000; Evans\& Green, 2006; Fauconnier \& Turner, 1998, 2002; Hart, 2016). The structure projected from the inputs is completed with that recruited from background frames, as Evans and Green (2006) point 
out. Elaboration (or running the blend) is the mental simulation of the event in the blend (Grady et al., 2007/1999, p.425). Upon running the blend, the additional structure emerges that has arisen as a result of composition and completion (Evans \& Green, 2006, p.411). The emergent structure developed in the blend can be projected back to the input spaces to modify them via backward projections (Fauconnier \& Turner, 2002).

\subsection{Types of Integration Networks}

Fauconnier and Turner (2002) classify networks into four main types along a continuum, all of which are powerful "tools of imagination" (p.139).

\subsubsection{Simplex networks}

According to Fauconnier and Turner (2002), they are the simplest kind of integration network, as they involve two inputs: one that contains an abstract frame and another that contains elements with no organizing frame They define the organizing frame as the one specifying "the nature of the relevant activity, events, and participants", while the abstract frame indicates no "cognitively representable type of activity or event structure" (p.104). An example of this type is human kinship: Peter is the son of Diana. The first input has a Family Frame with roles of mother and son; the second input has the values (the framed elements): Diana and Peter. Diana fills the role of mother; Peter fills the role of son. The frame and the values are fused in the blend, as Fauconnier and Turner (2002) stress.

\subsubsection{Mirror networks}

All the spaces in this network, including the blend, share a common organizing frame (Evans\& Green, 2006; Fauconnier \&Turner, 2002). Hence, the inputs do not have clashes between them (Fauconnier \& Turner, 2002). Example: in the BOAT RACE blend, all the four spaces contain the same frame in which a boat follows a certain course.

\subsubsection{Single-Scope networks}

According to Fauconnier and Turner (2002), each of the inputs contains a distinct frame but only one of them organizes the blend, i.e., the framing input provides the organizing frame, and the focus input provides the relevant elements. For example, Company A delivers the knock-out punch to company B; it activates the BUSINESS IS BOXING metaphor. The framing input is BOXING which includes the roles for 
boxers; the focus input BUSINESS contains the values company $A$ and company $B$.

\subsubsection{Double-Scope Networks}

The two input spaces contain distinct organizing frames that compose the blend (Fauconnier \&Turner, 2002; Turner, 2006). However, the structure resulting from inputs is sometimes incompatible and thus leads to clashes between the organizing frames, which render the blend extremely innovative (Fauconnier \& Turner, 2002). For example, computer desktop is a double-scope network with two distinct organizing frames: the frame of office work with folders, files,...etc. and the frame of computer commands. Elements do not clash although they belong to the different frames (Fauconnier \& Turner, 2002, p.131). Double-scope networks can, as Evans and Green (2006) claim, develop metaphorical blends. Fauconnier and Turner (2002) point out that "metaphoric integrations are typically single-scope or double-scope" (p.154). They assert that the integration networks can evoke emotions and generate inferences. Sometimes, the conceptual integration incorporates multiple input spaces; thus, it becomes a multiple blend where one blend functions as the input space for another.

\subsection{Metaphoric blends}

The visual representation of an abstract concept such as education - the focus of this study - "is utterly impossible without the mediation of metaphors" as El Refaie (2003) indicates (p.91). Fauconnier and Turner (2002) assert that metaphor plays a central role in human cognition. Similarly, Hart (2016) maintains that metaphor is a cognitive "ability to compare experience" via "mappings or projections between domains or spaces" (p.138). Moreover, Coulson and Matlock (2001) argue that "metaphor involves a complex of mappings with multiple spaces in conceptual integration networks" (p.300). El Arousy (2016) underlies that "inputs from both the cartoon caption and drawing help create metaphors as blends" (p.399). Such metaphoric blends strongly shape the way political issues are perceived (Abdel-Raheem, 2016).

Moreover, Grady et al. (2007/1999) maintain that "some blends depend on counterpart relations dictated by conventional metaphoric associations" (p.431). Fauconnier and Turner (2002) incorporate 
"metaphoric counterpart connections" among other types of relations connecting input spaces (p.47). Grady (2005) argues that although blending theory mentions metaphoric blends, it neither specifies the nature of metaphoric connections or the properties of metaphor. Fauconnier and Turner (2002) treat metaphors as analogical mappings. Grady (2005) clarifies that analogical mappings are associations based on shared features between concepts in source space and target space. However, Grady (2005) classifies metaphoric blends as a type of blend and addresses their properties. He argues that entrenched metaphoric counterpart connections between concepts "are motivated by ... correlations in experience" (p.1605) and provide the basis for online construction of metaphoric blends. Correlations must fulfill three conditions to produce metaphoric associations between concepts:

a) Sensory and nonsensory: Source concept constitutes aspects of sensory experience; target concept is associated with spects of mental experience, i.e., subjective interpretations, evaluations, or responses to sensory experience.

b) Shared superschematic structure: The two correlated concepts must be interpreted in terms of a common, highly schematic structure. They could be both construed as states, scalar properties, actions, events, entities, and atemporal relations.

c) Covariation: The two correlated concepts (heavy - difficult) must vary directly with each other; a difference in the source concept (heavier) must be accompanied by a corresponding difference in the target concept (more difficult).

Following Fauconnier and Turner (2002) and Grady (2005), this study addresses metaphoric blends in terms of metaphoric associations, whether they are derived from (i) analogical mappings (i.e., shared features) or (ii) recurring correlations in experience (guided by the 3 constraints)

\section{Political Cartoons}

According to Forceville (2016), cartoons are classified as "a fictional genre of visual art" (p.160). Fludernik (2015) simply defines a cartoon as "a drawing, usually published in a newspaper or magazine, that does not have an exclusively mimetic purpose of illustration". Bounegru and Forceville (2011) and Forceville (2016) stress that a political cartoon 
often criticizes a public figure or an event in the world in a humorous way. Cartoons differ from caricatures, which are "exaggerated portraits of known people" (Forceville, 2016, p.159). Although political cartoons do not occupy a lot of space, as El Refaie (2009) points out, they can convey messages via a single image incorporating complex information. However, Fludernik (2015) asserts that when cartoons convey a political message or tackle a serious topic, their "comic potential is backgrounded or comes to support the message" (p.170). El Refaie and Hörschelmann (2010) maintain that cartoonists shape the cartoons to reveal certain meanings within a certain socio-cultural context; they also employ symbols, metaphors, and metonyms, assuming that they are common enough to be interpreted. For this reason, Bounegru and Forceville (2011) argue that metaphor is the cartoonist's tool to deliver satirical messages and reveal his ridiculing stance (p.224).

Accordingly, Fludernik (2015) asserts that cartoons act as "illustrative material used to explicate visual metaphor" (p.157), and that "Metaphoric cartoons are clearly instances of visual blending" (p. 162). Similarly, Croft and Cruise (2004) assert that cartoons trigger visual conceptual blending. Blending in political cartoons, as Coulson (2005) asserts, serves to "project political actors and events into new contexts where the cartoonist's point can be hyperbolically illustrated" (p.118). Coulson (2006) claims that political cartoons "represent the contents of a blended space and invite the viewer to unpack it into its inputs" (p.197). Grady, Oakley and Coulson (2007/1999) claim that unique novel blends in cartoons, jokes and newly coined terms are created and interpreted easily. Consequently, this implies that the processes employed to construct and construe blends are embedded cognitive ones. Consequently, blending theory, as Forceville (2016) notes, helps in understanding political cartoons.

\section{Methodology}

\subsection{Data Selection}

The data comprise five online cartoons selected from the website of the cartoonist, Dr. Sherif Arafa, who is also a physician, a writer, and a specialist in positive psychology. The five cartoons portray the problems of education in Egypt; they are traced back to the years 2010-2011. The 
cartoons were collected from his website (http://drsherif.net, accessed 10 May 2016). The selection of the five cartoons is based on a tentative analysis that revealed the establishment of metaphoric associations between input spaces and spotted features of blending.

\subsection{Procedure of Analysis}

The study adopts Fauconnier and Turner's (2002) theoretical framework and Grady's (2005) specifying features of metaphoric blends. The analysis of the five cartoons proceeds as presented in table 1 below:

Table 1. Procedure of analysis

\begin{tabular}{|c|c|}
\hline 1. & Description of the cartoon context \\
\hline 2. & Type of triggered network (Fauconnier \& Turner,2002) \\
\hline \multirow[t]{2}{*}{3.} & $\begin{array}{l}\text { Three blending processes: composition, completion, and } \\
\text { elaboration }\end{array}$ \\
\hline & Emergent inferences \\
\hline 4. & Interplay between the visual and verbal modes \\
\hline 5. & Realization of metaphoric blends (Grady, 2005) either via: \\
\hline A & Analogy ( shared features) \\
\hline
\end{tabular}

\section{Analysis of Metaphoric Blends}

Cartoon 1 tackles the problem of education in Egypt in general, cartoons 2- 4 address the problem at the school level, and cartoon 5 tackles the problem at the university level. In each cartoon, the mappings between the elements or relations in the input spaces are shown both in a tabular form and in a diagram.

Cartoon 1: Education

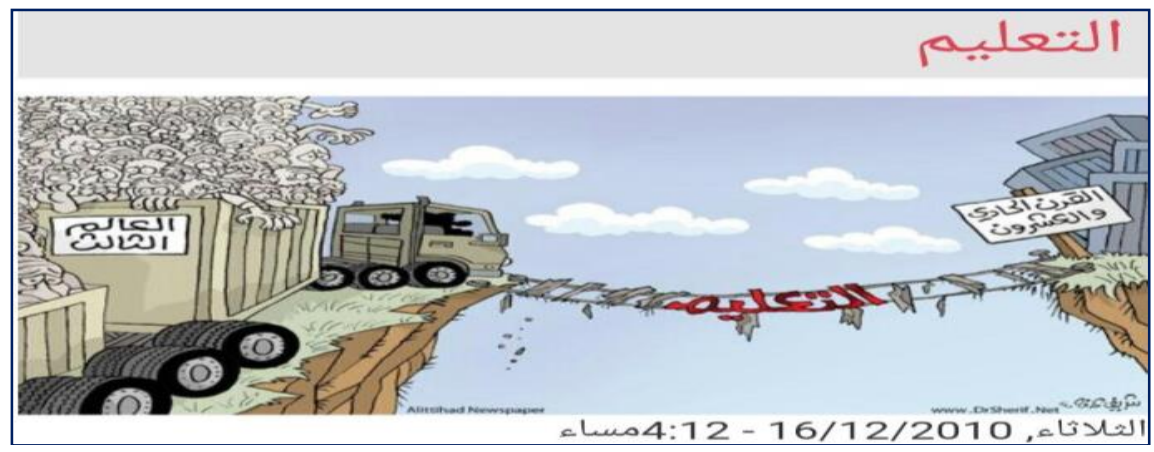

The cartoon depicts a heavy loaded double trailer dump truck loaded and bursting with people who seem miserable, pathetic, and scared. The truck is heading towards a worn out, hanging rope bridge with several broken or even missing wooden planks connecting two mountain cliffs. 
The cartoon evokes a vivid double-scope integration network with two mental spaces containing elements from two organizing frames: education and bridge, respectively. The first input space is verbally triggered via the caption and its reiteration in the inscription on the bridge /لتعليم// (education); the second is visually triggered via the drawing/image of the bridge. The counterpart elements are linked by metaphorical connectors across the two frames, evoking the following blend:

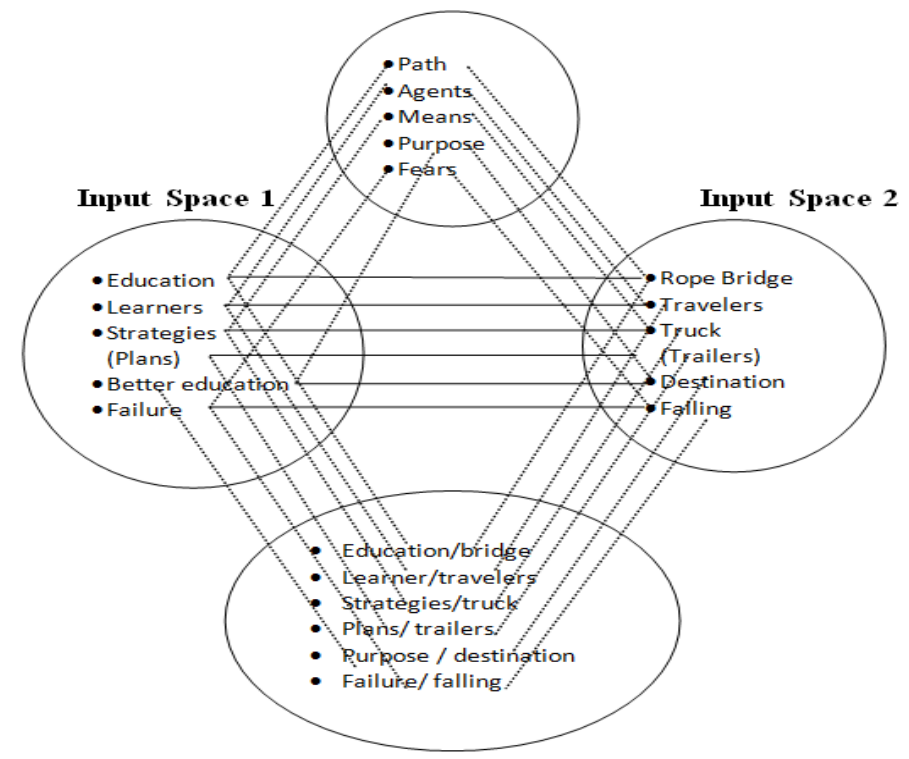

Figure 2. The integration network in cartoon 1

The cartoonist construed the educational status metaphorically in terms of an almost collapsing hanging rope bridge. The mapping between education and the rope bridge is cued explicitly by the verbal inscription education. The image of the trailers, as large containers carrying many people and moving forward, matches the means of education (schools and classrooms). They are like a straitjacket, with no development, to accommodate for all students and broaden their horizon. The learners look desperate, seeking help before the van falls into the abyss, hardly aspiring to reach the threshold of the $21^{\text {st }}$ century (i.e. modern world), which is metonymically represented by the image of the sky scrapers and the verbal inscription / القرن الحادى و العشرون /21/21 century. It can be inferred from the verbal inscription العالم الثالث (the Third World) that Egypt, a part of the Third World, cannot embark on the threshold of the $21^{\text {st }}$ century except through an advanced, sophisticated system. The means/strategies 
of education represent a bounded material entity overflowing with desperate learners. Steering the vehicle corresponds to adopting education policies; strategy failures correspond to falling into the abyss; vehicle destination corresponds to the $21^{\text {st }}$ century. Some counterpart elements are selectively projected from the two input spaces to the blend, where they are integrated to develop a novel, emergent structure via completion, composition, and elaboration, respectively.

Table 2. Mappings for EDUCATION as A BRIDGE

\begin{tabular}{|l|l|}
\hline Input Space 1 & Input Space 2 \\
\hline Education Frame & Bridge Frame \\
\hline Learners (Students) & Travelers \\
\hline Path: Education System & Path; Hanging Rope Bridge \\
\hline Means: Strategies of Education & $\begin{array}{l}\text { Means: Double Trailer Dump } \\
\text { Truck }\end{array}$ \\
\hline Crowded Classes or Schools & Two Trailers \\
\hline Strategy Maker & Truck Driver \\
\hline Steering the Vehicle & Adopting Education System \\
\hline $\begin{array}{l}\text { Two Different Systems of } \\
\text { Education }\end{array}$ & $\begin{array}{l}\text { Two Continents }\left(3^{\text {rd }} \text { World vs. }\right. \\
\text { Developed Countries }\left(1^{\text {st }} \text { World) }\right.\end{array}$ \\
\hline $\begin{array}{l}\text { Purpose a Better Education } \\
\text { System }\end{array}$ & Purpose/Destination 21 st Century \\
\hline Failures of Strategies & Falling into the Abyss \\
\hline Improving Education & Crossing the Rope Bridge \\
\hline
\end{tabular}

Composition: Selected counterpart elements are projected from the two input spaces and fused in the blend; education is fused with the rope bridge. 'Learners' are metaphorically mapped onto 'travelers'. The 'strategies' are fused with the truck; the trailers, as bounded entities, could also be mapped onto the overcrowded, cramped classrooms or schools. Failure of strategies corresponds to falling down. Achieving a purpose-which is a better education-matches arriving at a destination, which is embarking on the threshold of the $21^{\text {st }}$ century.

Completion recruits background knowledge frame of an old collapsing bridge to the blend which completes the structure projected from the two input spaces. Thus, the frame of a bridge about to fall down is activated, whereby the structure stability of a dilapidated hanging rope bridge between two mountain cliffs cannot be guaranteed. Completion 
also recruits stored representations of a dangerous voyage in which a heavy loaded truck moving over such a bridge in an attempt to reach its destination is doomed to fall down into the abyss shown beneath. From input space 1, the blend recruits the education frame, the futile education policies, the overcrowded classrooms, and the parochial curricula, all of which render coping with developed nations a far-fetched dream.

Elaboration involves mental simulation, where the learners stuck in the overcrowded trailers fear falling down and may be destined to die, as the rope bridge with the missing or broken wooden planks collapses. Thus, in the blended space, the emergent inference is that the current incompetent education system and the parochial (straitjacket) educational strategies are doomed to fail. Consequently, they will not help in embarking on the threshold of the $21^{\text {st }}$ century; they will eventually herd the miserable people/learners into the abyss of underdevelopment. The implied message is a demand to mend the education system and its policies, as underdevelopment is an unavoidable outcome. Another generated inference is related to the classrooms or schools stuffed with students, thus failing to provide quality education. Hence, it can be inferred that enrollment in schools is high; the quality of education is low, i.e., the system has provided access but not quality. Consequently, such inferences express the cartoonist's stance and can be projected back to the 1 st input space, hence updating the EDUCATION frame. The creative cross-space mappings of the elements from the two input spaces are compressed into the blended space. The distance between the two distant worlds is compressed in the blend into syncopated space (Fauconnier \&Turner, 2002), where it represents points of departure and destination.

The caption and the inscriptions in cartoon 1 render it readable, and together with the image, they prompt for the visual construction of a metaphoric blend. The cartoonist construes the education status metaphorically in terms of a bridge. It is evident that the visual and verbal context plays a role in interpreting the underlying message in the cartoon. Plausibly, the cartoonist prompts the reader to unravel the meaning constructed via the interplay between the verbal input space 'education' and visual input space 'bridge', which triggers visual conceptual bending. Hart (2016) points out that "the construal operation of blending... 
accounts for the ideological and legitimating functions of metaphor in discourse" (p.142). Accordingly, the metaphoric blend accounts for the cartoonist's ideological thrust: education in Egypt needs major and radical corrective measures to cope with the cutting-edge knowledge and technology of the First World/developed countries. The cartoonist offers insights into the current education system, its ailments, and the failure of its strategies.

According to Grady (2005), the cartoon triggers a metaphoric blend on the basis of experiential correlations. The two concepts, education and the bridge, meet the three constraints set by Grady (2005). The source concept 'bridge' is sensory; the target concept 'education' is nonsensory. Both terms share a superschematic structure as linking entities. Both exhibit covariation, where the more dilapidating a bridge becomes, the more crumbling education strategies become. As a bridge can connect two places, education can connect two worlds and cultures. Thus, the creative cross-space mappings of the elements from the two input spaces are metaphoric.

\section{Cartoon 2: Exams}

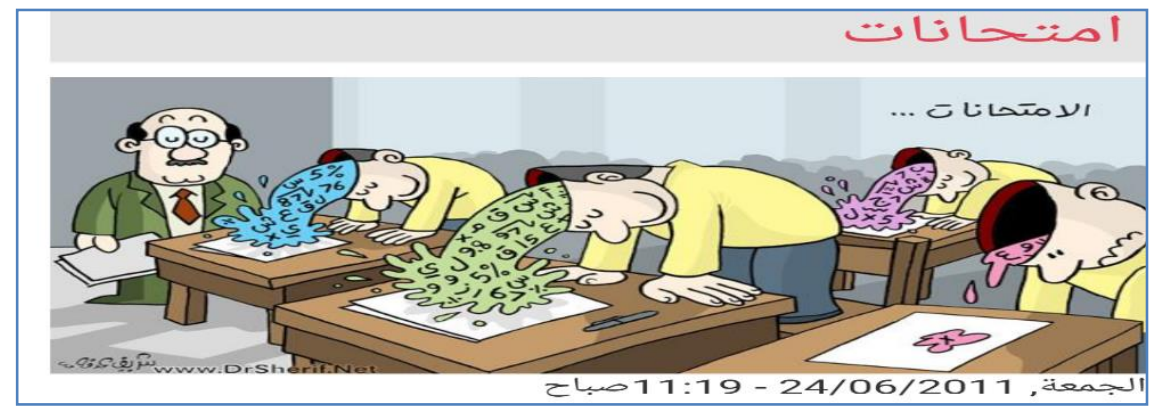

This cartoon depicts students having an exam; a teacher proctoring the exam; and the pens are placed intact on the desks. Students are even depicted as standing on the chairs rather than sitting at the desks. Their hands are placed on the desks to assist their body posture in spouting all the information stored in their brains at varying degrees rather than writing neatly with their pens. The cartoon evokes a double-scope integration network with two input spaces, each organized by a distinct frame: a test-taking frame from school and pouring liquid frame from a container (for example, a pitcher) to a glass. There are conceptual clashes between the input spaces of pouring liquid and test-taking. Such clashes 
"offer challenges to the imagination of the cartoon reader" (El Arousy, 2016, p.397). This cartoon triggers a metaphoric blend that construes information as a fluid in a container. The cartoonist renders the students' minds as containers spouting information, probably with little understanding.

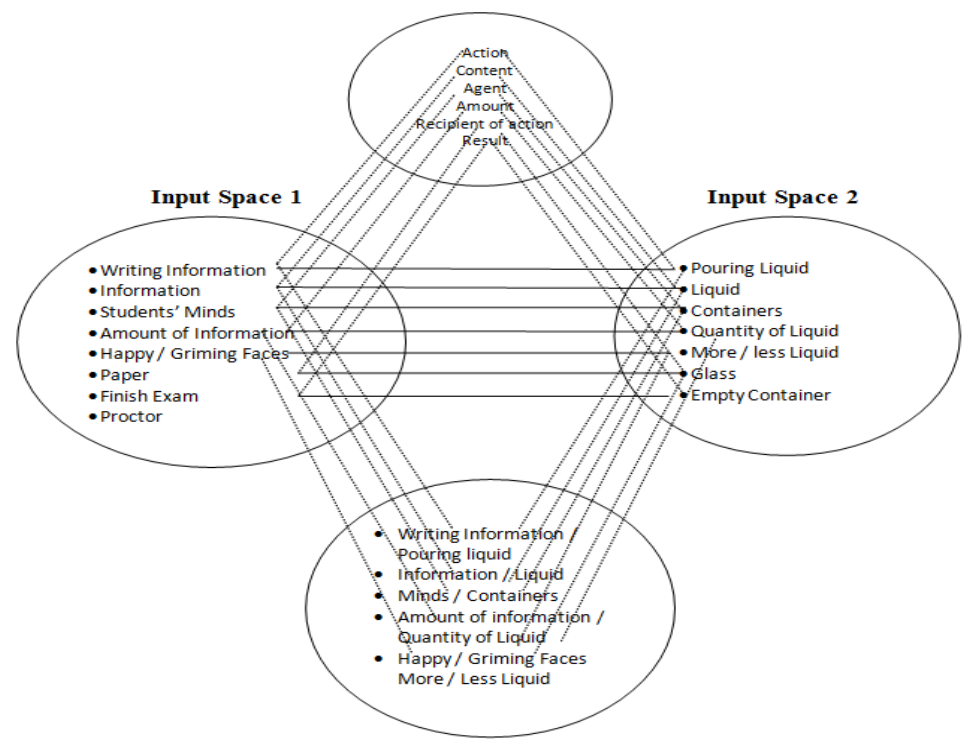

Figure 3.Integration network in cartoon 2

The depicted image activates the conventional ontological metaphor "MIND IS A CONTAINER"-which is visually realized in the cartoonfor ideas, information, and all subjects studied (see Lakoff \& Johnson, 1980). Fauconnier and Turner (1998) assert that speakers "recruit entrenched projections" to construct "on-line conceptual projections" (p.161). Similarly, Grady et al. (2007/1999) highlight that "conventional metaphors feed the blending process by establishing links between elements in distinct domains and spaces" (p.428). The counterparts evoked by the conventional metaphor trigger the blend. The container matches the mind; the liquid corresponds to stored information. The image draws the viewer's attention to the ways in which the answers are assessed, the more students spout stored information, the better the results are. The opposite is also true. The cartoon thus hints at the defective futile education system that obliterates creative thinking and analysis and advocates memorizing. Consequently, the end result is an incompetent 
mal-educated student. As Fludernik (2015) asserts "The fictional world of the cartoon is a spoof' (p.157).

Table 3. Mappings for TEST-TAKING as POURING LIQUID

\begin{tabular}{|l|l|}
\hline Input Space 1 & Input Space 2 \\
\hline Test- Taking Frame & Pouring Liquid Frame \\
\hline Knowledge/ Information & Liquid \\
\hline Writing down the Information & Pouring the Liquid \\
\hline Students' Minds & Containers \\
\hline Amount of Knowledge & Quantity of Liquid \\
Happy Facial Expression & More Liquid \\
Griming Face & Less Liquid \\
\hline Finish Exam & Empty the Container \\
\hline Paper & Pitcher \\
\hline Proctor & --------- \\
\hline
\end{tabular}

Composition: Some elements of structure are projected from the pouring input space while other elements are projected from the testtaking space to the blend. The information from the test-taking frame is projected to the blended space to be fused with the liquid from the container frame. Writing down all the stored information is fused with pouring down all the liquid in the container. The element 'students' minds' is projected to the blend to be fused with the 'containers'. The amount of stored information is fused with the quantity of liquid. The information encompasses all the subjects- as depicted in the cartoonmemorized and stored in the students' brains, and retrieved in an exam. The non-verbal facial expressions reflect that the more information the brain spouts, the happier and more relaxed the student becomes, and vise versa. El Refaie (2009) asserts that the viewer's ability to interpret the cartoon characters' facial expressions and gestures helps him to interpret the meaning of the cartoon. In the blend the happy facial expressions are fused with more liquid, whereas griming faces are fused with less liquid.

Completion: This cartoon activates one of the cultural models which Coulson (2005) defines as "socially shared frames" (p.107), i.e., answering an exam means spouting all stored information. The blend recruits the background knowledge frame of EXAMS, where writing answers implies an automatic process of spouting/pouring all stored 
information. The more students know, the more they write, and vise versa. It activates the background frame of pouring liquid from a pitcher to a glass, as if learning incorporates pouring knowledge from mind to mind. Students lack the skill of creative and critical thinking, which highlights the futile system of learning. The frame of soaking is also recruited, where pouring a liquid on a paper instantly soaks it. The liquid, in input space 2, contains mathematical symbols, letters, and numbers that should appear on paper; in the test-taking input space, the paper does not get wet, but in the blend the liquid 'soaks' the paper. The more liquid the students spout, the more soaked the answer sheet gets. Consequently, it can be inferred that the students lack creative thinking skills. The recruited knowledge frames completes the structure projected from the inputs and integrates it in the blend.

Elaboration: running the blend involves mental simulation. In the blend, the information is a liquid that soaks the paper and even spills on the ground. The emergent inference is that the process of retrieving stored information is unconsciously triggered; exam questions do not assess students' creativity or critical thinking or even analysis. Learning is based on memorizing and obliterates aptitude. This cartoon involves compressions of events to human scale, where exams involve going to school, attending classes, doing homework, and studying. Exams compress, into one or two hours, one academic/scholastic year of being a student, so the vital relation of time is compressed into scaled time in the blend.

The test-taking input space is cued both verbally via the caption entitled امتحانات (exams) and visually through the pictorial context. The caption "exams"- the verbal representation of the target input spacemetonymically pertains to the education domain. The caption 'exams' provides the verbal input space and the image provides the visual input space 'pouring liquid'. The image is expressive and the blend can be effortlessly interpreted and constructed from the visual context. The cartoonist assumes the existence of shared background knowledge with the reader/viewer, and hence the viewer can assume a number of mappings between the input spaces, which facilitates the interpretation of metaphoric blends. Both the cartoonist and the viewer share the 
background knowledge that Egypt has serious education problems. Along the same line, El Arousy (2016) concludes that "readers construct meanings, not only through the verbal and pictorial inputs, but also through shared knowledge with the cartoonist" (p.413). Coulson and Oakley (2000) also highlight that the viewer's/reader's background knowledge, contextual information, and cognitive abilities lead to a successful meaning construction.

The cartoon triggers a metaphoric blend based on experiential correlations. According to Grady (2005) the two concepts, taking a test and pouring liquid, meet the three criteria of metaphoric blends. The source pouring liquid is sensory; the target taking the test is nonsensory, as it targets one's evaluation. The two concepts are regarded as events in terms of the superschematic structure. Moreover, the more liquid is poured, the more information is written on the answer sheet. Consequently, the difference in the quantity of the liquid is associated with the difference in the amount of written information. The two concepts in the exam scenario vary directly with each other.

Cartoon 3: Building a human being

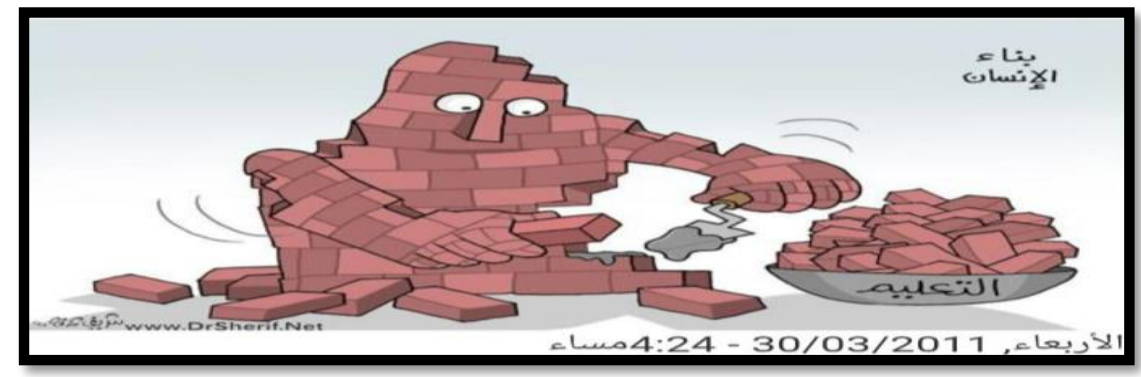

The cartoon depicts an incomplete deformed brick construction which personifies a human being with wide eyes attempting in vain to finish building (i.e., constructing) himself. Personification, as El Refaie (2003) argues, is the cartoonist's tool of presenting serious topics in a simple way. The constructed figure is endowed with human qualities such as incapability and incompetence. It is clear that in his vain attempt to fill and finish the joints between the bricks with mortar or cement using the primitive pointing trowel as a construction tool, the bricklike human being lacks the knowhow of self-construction. Consequently, deformity dominates, encompassing the head, the arms, and the torso. 


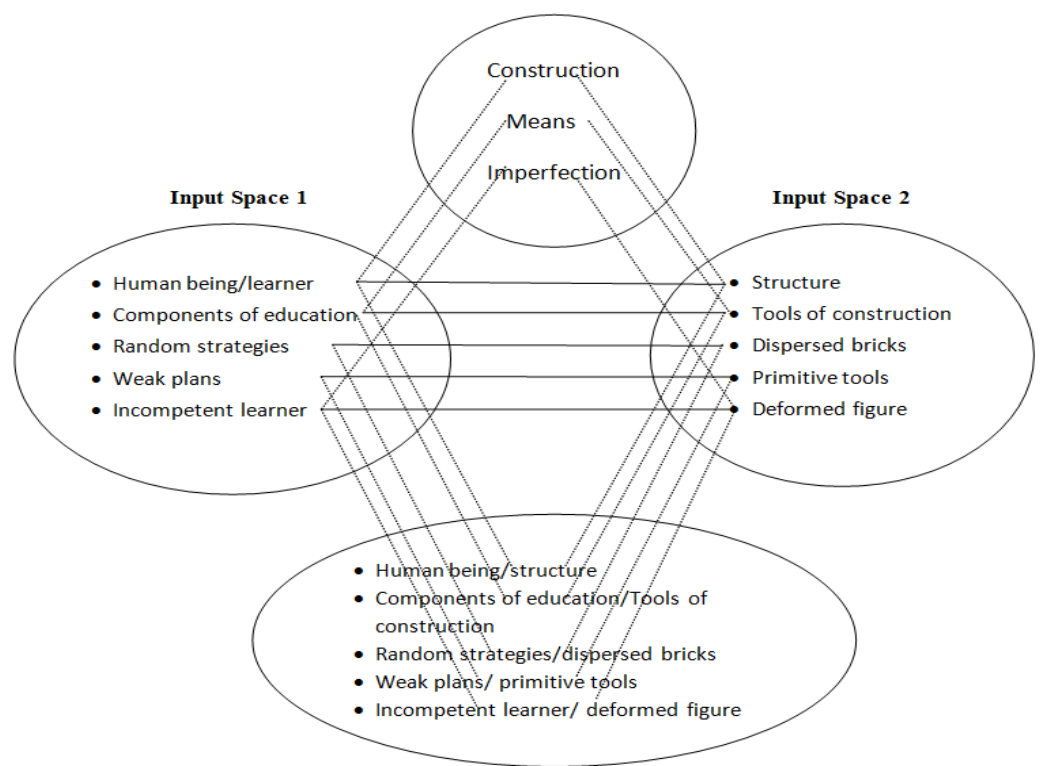

Figure 4. Integration network in cartoon 3

The cartoon prompts for a double-scope integration network with two input spaces: building construction and education. Fauconnier and Turner (1998) stress that in metaphoric cases the two inputs are the 'source input' and the 'target input'. The first input space embraces 'education' as evident from the verbal inscription /التعليم/(education); the second input 'building construction' is visually and verbally cued. The two frames BUILDING CONSTRUCTION and EDUCATION organize the blended space. Fauconnier and Turner (1998) comment that "The blend inherits the concrete structure of building from the source input" (p.150).

Table 4. Mappings for EDUCATION as BUILDING CONSTRUCTION

\begin{tabular}{|l|l|}
\hline Input Space 1 & Input Space 2 \\
\hline Human Being & $\begin{array}{l}\text { Structure (is personified, no } \\
\text { physical agent) }\end{array}$ \\
\hline $\begin{array}{l}\text { Components of Education } \\
\text { (Plans, Policies, Curricula, } \\
\text { Teachers/ Methods of Teaching) }\end{array}$ & $\begin{array}{l}\text { Tools of Construction } \\
\text { (Bricks, Mortar/ cement, } \\
\text { Masonry Pointing Trowel, Head } \\
\text { Pan) }\end{array}$ \\
\hline Random Strategies & Dispersed Bricks \\
\hline $\begin{array}{l}\text { Incompetent Learner } \\
\text { (incompetency) }\end{array}$ & Deformed Figure(deformity) \\
\hline
\end{tabular}




\section{\begin{tabular}{|l|l|}
\hline Weak Strategies & Primitive Tools \\
\hline
\end{tabular}}

Composition: In the blend, the material construction process and education are two constructing processes with varied orientations: erecting a building and building a human being. The blend inherits properties from each frame. In the blend, the material structure is fused with the human being (its counterpart); tools of construction with components of education; dispersed bricks with random strategies; and deformity with incompetency; and weak strategies correspond to primitive tools. In the blend, the human being is conceptualized as a deformed material structure.

Completion: The blend recruits knowledge from the BUILDING CONSTRUCTION frame to highlight the outcomes of an incompetent education system. Through completion, just as the primitive building tools fail in erecting a well-built structure, the weak incompetent education strategies fail to build a competitive citizen. Consequently, deformity is the unavoidable outcome. The education system in Egypt needs corrective measures.

Elaboration: The novel emergent structure in the blend fuses with the partial structure from the input spaces to create the blended concept, as Coulson (2006) remarks. Elaboration involves mental simulation, where education strategies are seen as bricks used to build education system. Educating a human being means building him. The metaphoric blend seems to present incompetent, retarded education system as a deformed, incomplete physical structure. The evoked inference is that low competence and deformity are the lethal consequences of an incompetent education system.

The linguistic (verbal) cues in addition to the image help the viewer/reader to identify the mappings between the counterpart elements of the two input spaces. The caption بناء الإنسان(building a human being) enhances construal of the cartoon. The random strategies of education and the dispersed bricks are counterparts in the two input spaces, respectively. The verbal inscription التعليم (education) evokes the abstract frame of education with its policies, methods, curricula. This agrees with El Refaie's (2003) argument that verbal context is indispensible in indicating "the visually absent concept" (p.91). 
The metaphoric blend triggered in this cartoon is based on experiential correlations. The source 'building construction' is sensory; the target 'education' is nonsensory, as it targets one's evaluation. The two concepts are regarded as events in terms of the superschematic structure. Moreover, the two concepts vary directly with each other. The better the education is, the more competent the individual becomes.

Cartoon 4: Pedagogy and Education

(based on the video of the ferocious teacher)

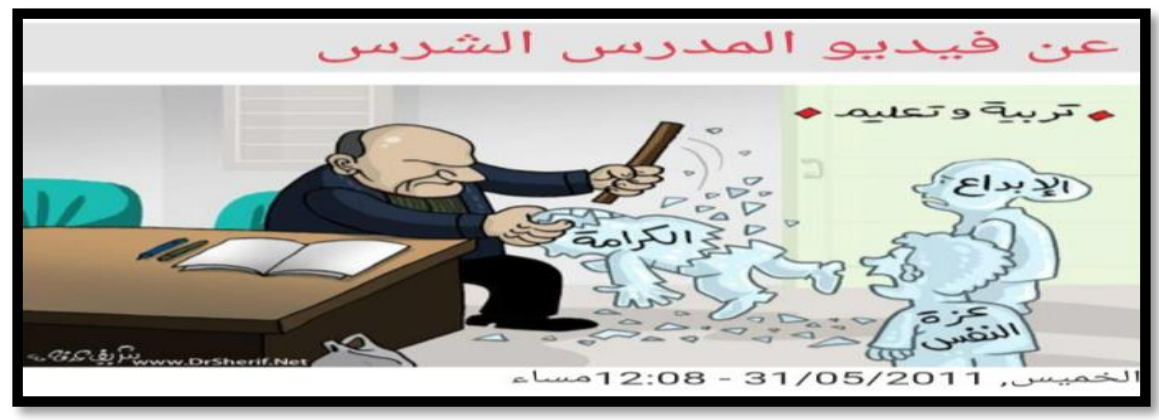

This cartoon depicts a violent, aggressive teacher sitting at his desk, beating one of the students with a stick; the other two are fearfully waiting for their turn. Broken fragments are scattered everywhere. This cartoon appeared after a video of a violent Egyptian teacher beating innocent students was uploaded on YouTube, which aroused a wave of anger. The three verbal labels/inscriptions: creativity, dignity, and selfesteem (integrity)- imprinted on the statues representing the studentssignify three intrinsic qualities that should be cherished rather than destroyed. The teacher metonymically represents the education system. 


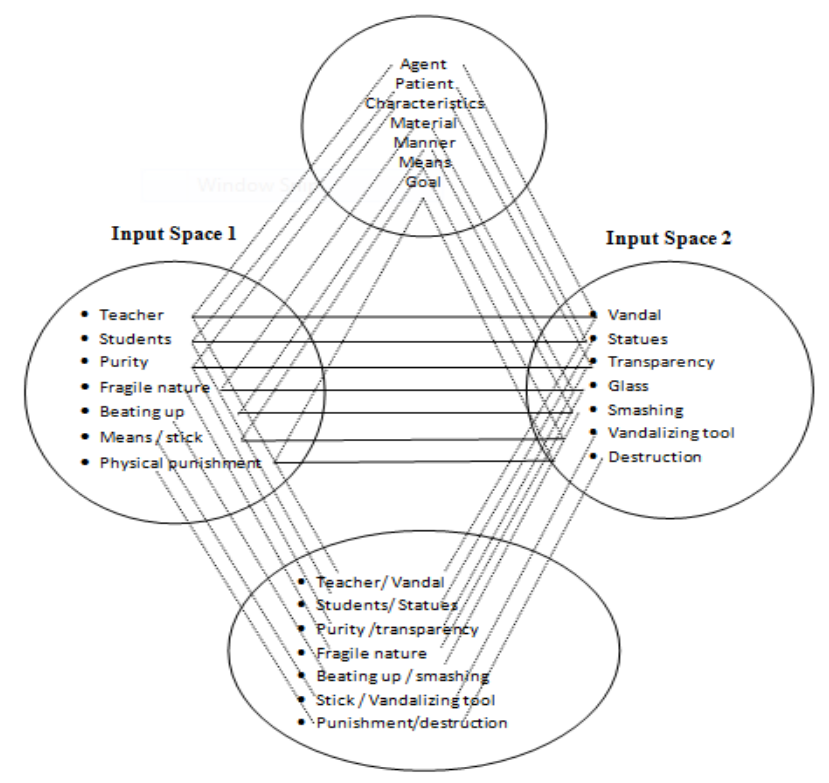

Figure 5. The integration network in cartoon 4

The cartoon represents a double-scope integration network with two input spaces, each structured by a distinct frame: teacher and statue vandal. Elements projected from each frame organize the blend. The teacher in target input space 1 maps onto the statue vandal in the source input space 2. The stick corresponds to the tool of destruction; the stick evokes connotations of abuse and aggression. Statues are emblems of creativity ابداع/, dignity/ الكرامة/, and self -esteem (integrity)/ عزة النفس/. The fragile students are connected to the glass statues by means of a pragmatic function connecting representations and the things that they represent (Coulson \& Oakley, 2000, p.177). The transparency of the glass reflects the students' purity and innocence. The mappings between the two input spaces can be represented as follows:

Table 5. Mapping for TEACHING as VANDALISM

\begin{tabular}{|l|l|}
\hline Input Space 1 (Teaching) & Input Space 2 (Vandalism) \\
\hline Agent: Teacher & Agent: Statue Vandal \\
\hline Patient: Students & Patient: Statues \\
\hline Purity & Transparency \\
\hline Fragile nature & Glass \\
\hline Manner: Beating up & Manner: Smashing \\
\hline Means: Stick & Means: Vandalizing Tool \\
\hline
\end{tabular}




\begin{tabular}{|l|l|}
\hline $\begin{array}{l}\text { Goal: Physical Punishment, } \\
\text { Torture }\end{array}$ & Goal: Destruction \\
\hline Three Qualities & Three Inscriptions \\
\hline
\end{tabular}

Composition: The blend inherits structure from the input spaces of teaching and vandalism. The selectively projected elements are connected to their counterparts. The blended space recruits the goal of the vandal and fuses it with the manners of the teacher and the means he employs. In the input space of vandalism, the statue vandal smashes statues, shattering them all around. However, in the blended space such loathsome behavior is brutal and is rejected in teaching students in a classroom. While teachers are expected to build students' characters, vandals destroy statues. In the blend, the teacher is conceptualized as a statue vandal.

Completion: the cartoon recruits the familiar background frame of physical and emotional abuse and activates one of the cultural models: teaching is a physical punishment, rather than a pedagogical process, a matter that became entrenched in the society, yet rejected.

Elaboration: the metaphoric blend simulates the image of a statue vandal smashing the students with a club or even a more grotesque image of parts of their bodies torn out and scattered all around; blood oozes and tarnishes everything. It is possible to imagine various scenarios. A newly emergent structure is triggered combining elements from the two input spaces. The emergent inference that arises when elements of the blend are elaborated is that the teacher, who is unable to restrain his brutality, is incompetent and aggressive (a vandal); he destroys-rather than builds upthe positive qualities and characters of the students. The goal and the appalling behavior of the statue vandal (i.e., smashing and destruction) suit the vandal but are unacceptable for a teacher and the teaching process in classrooms.

The cartoonist employs 'compression' to human scale as he compresses the complex teaching process into one scene. Thus, the outerspace metaphoric relation between the teacher and the statue vandal is compressed into inner-space uniqueness in the blend: the aggressive teacher is a vandal. The two elements of the two input spaces (students and statues) are connected via an outer-space relation of representation which has been compressed into the inner-space uniqueness. In the blend, 
the statues are the students; the two distinct entities are understood as the same entity. It can be argued that the cartoon conveys ethical messages about the role of a teacher and evokes the viewer's empathy for the students. Violence and abuse are rejected, negative attributes. Consequently, the cartoonist engages the viewer in a call for raising the standards of Egyptian schools, especially teachers.

The cartoonist employs the caption as a cue for the first input, the teacher, and the second input space is cued via the visual context (i.e., the image). The teacher is portrayed as a statue vandal; the students as glass statues. The cartoonist satirically uses the caption تربية وتعليم (pedagogy and education) to criticize the teaching methods, which totally contradict what the caption implies.

The cartoon triggers a metaphoric blend via analogical mappings. The two concepts, teacher and vandal, are associated in terms of destruction and abuse. The teacher destroys the students physically and psychologically via beating; the vandal destroys statues per se.

\section{Cartoon5: Supply and Demand}

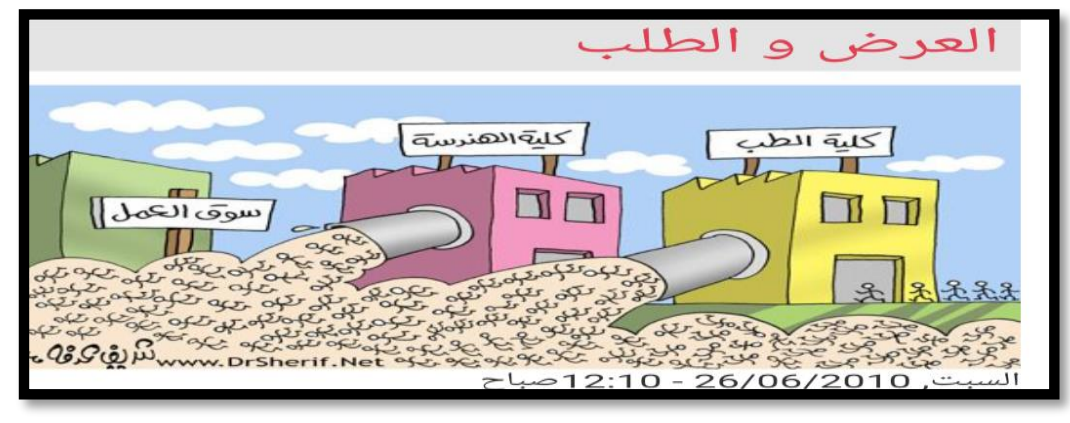

The cartoon depicts three buildings representing top (highly-ranked) faculties in Egypt, two of which are the faculty of medicine and the faculty of engineering. Huge numbers of students enroll in the faculties, and even larger numbers of graduates are pumped via two massive drainage tubes into (the labour market), inundating it as a flood. The verbal inscriptions, /كلية الطب/faculty of medicine, كلية الهندسة/faculty of engineering, and labour market, render the cartoon readable. Moreover, the visual context enhances construing the cartoon. 


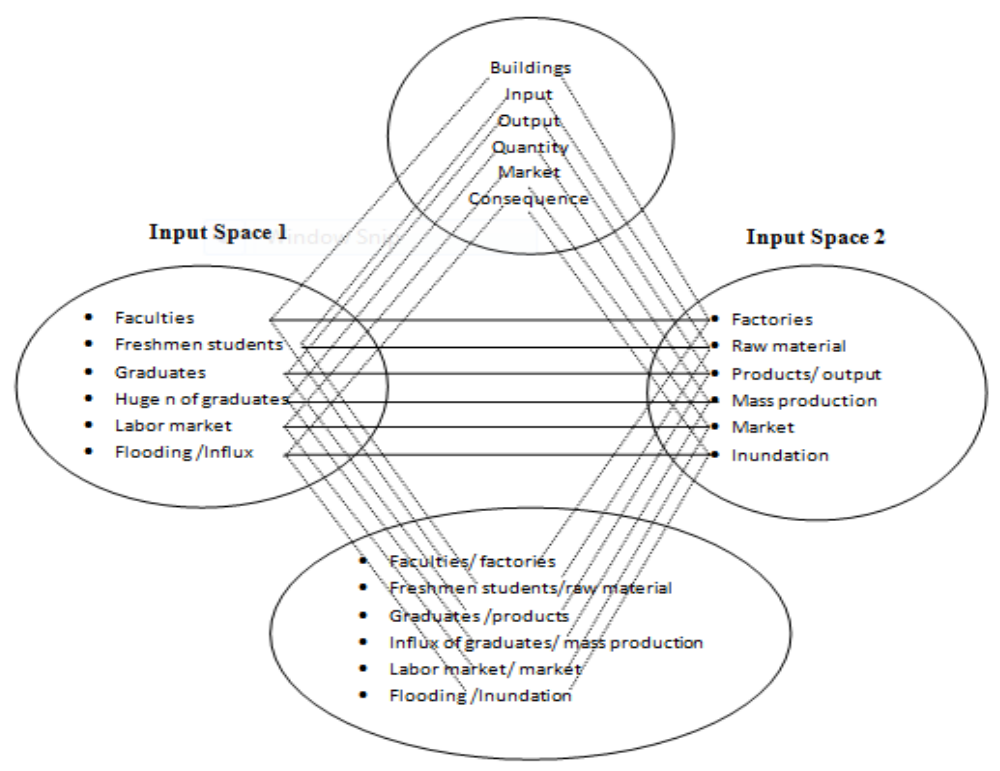

Figure 6. The integration network in cartoon 5

The image evokes a double-scope network with two input spaces, each having a distinct frame. The faculty input space and the factory input space. The caption is entitled 'supply and demand'. The mappings between the two input spaces can be presented as follows:

Table 6. Mappings for FACULTIES as FACTORIES

\begin{tabular}{|l|l|}
\hline $\begin{array}{l}\text { Input Space 1 (FACULTY } \\
\text { Frame) }\end{array}$ & Input Space 2 (FACTORY Frame) \\
\hline Faculties & Factories \\
\hline Students & Raw Material as Input \\
\hline Graduates & Products as Output \\
\hline Enormous Numbers of Graduates & Mass Production \\
\hline Labour Market( abstract concept) & $\begin{array}{l}\text { Market in General( concrete } \\
\text { concept) }\end{array}$ \\
\hline Flooding/ Influx of Graduates & Inundation \\
\hline
\end{tabular}

The emergent structure in the blend is developed via three processes. Composition: Selected counterpart elements are projected from the two input spaces and fused in the blend, creating a new emergent structure. In the blend, the element ' faculties' is projected from the faculty input space to be fused with the element 'factories' from the factory input space; 'students' from the faculty frame is mixed with 'raw material' from the 
factory frame; 'graduates' is fused with 'products' ; and labor market is fused with market. 'Enormous numbers of students' from the FACULTY frame is fused with 'mass production'. Flooding/Influx of graduates from the FACULTY frame is fused with inundation in the blended space.

Completion: The cartoon recruits background knowledge frame of drainage, where factories install huge drainage pipes to get rid of excess waste. Similarly, faculties dump excessive numbers of graduates into the labor market. Another activated background frame is the huge pump, spouting massive numbers of graduates who inundate the labour market to the extent that supply is much more than demand. That is why the rate of unemployment is increasing. Consequently, there is an additional structure introduced to the blend to complete the structure projected from the two input spaces.

Elaboration: Upon running the blend, the viewer can undergo a mental simulation, where he imagines massive numbers of graduates coming out of factory drainage pipes as excessive waste only to be dumped away. The graduates can also be seen as spouted out of giant pumps, whereby they flood the labour market. The emergent meaning in the blended space reveals that education-at the university level-fails to meet the basic requirements of the labour market; the graduates inundate the labour market. The number of graduates, even of the top faculties, is higher than the demand of the labour market; the end result is unemployment, which implies a need to adopt education strategies that would reduce the number of students enrolling in the university. Hence, the cartoonist is criticizing current education strategies which eventually lead to a waste of time, money, effort, and energies. The cartoon evokes a cultural model concerning the large number of unemployed graduates that inundate the labour market.

It is clear that the double-scope integration network is prompted by the visual context and the verbal inscriptions. The first input space is triggered by the verbal text (i.e., the inscriptions): faculty of medicine and faculty of engineering. The second input space is construed via the visual context (i.e., the image of factories). The caption 'supply and demand' intertwines the two spaces under one topic; hence, the cartoonist message is easily construed. The two input spaces activate the conceptual 
metaphoric blend which could be verbalized as faculties are factories inundating the labour market with enormous number of graduates to the extent that the offer exceeds the demand. Eventually, the graduates face unemployment.

The metaphoric blend is based upon analogical mappings where the two concepts: faculties and factories are both entities that share features such as mass production and market inundation.

\section{Results and Discussion}

The analysis of the five cartoons can be summed up as follows:

Table 7. Results of analysis in a tabular form

\begin{tabular}{|c|c|c|c|c|c|}
\hline $\begin{array}{c}\text { Cartoo } \\
\mathbf{n} \\
\text { numbe } \\
\mathbf{r} \\
\end{array}$ & $\begin{array}{c}\text { Year of } \\
\text { publicatio } \\
\text { n }\end{array}$ & $\begin{array}{l}\text { Type of } \\
\text { networ } \\
\quad k\end{array}$ & $\begin{array}{l}\text { Visual/verb } \\
\text { al modes }\end{array}$ & $\begin{array}{l}\text { Metaphori } \\
\text { c blend }\end{array}$ & $\begin{array}{l}\text { Inferences/nov } \\
\text { el meaning }\end{array}$ \\
\hline 1. & 2010 & $\begin{array}{l}\text { Double- } \\
\text { scope } \\
\text { network }\end{array}$ & $\begin{array}{l}\text { Input space } \\
1 \text { : verbal } \\
\text { (caption \& } \\
\text { inscription) } \\
\text { Input space } \\
\text { 2: Visual }\end{array}$ & $\begin{array}{l}\text { Experientia } \\
1 \\
\text { correlation }\end{array}$ & $\begin{array}{l}\text { Education } \\
\text { system needs } \\
\text { corrective } \\
\text { measures / } \\
\text { enrollment rate } \\
\text { is high; quality } \\
\text { education is } \\
\text { low. }\end{array}$ \\
\hline 2. & 2011 & $\begin{array}{l}\text { Double- } \\
\text { scope } \\
\text { network }\end{array}$ & $\begin{array}{l}\text { Input space } \\
\text { 1: verbal } \\
\text { (caption \& } \\
\text { inscription) } \\
\text { Input space } \\
\text { 2: Visual } \\
\end{array}$ & $\begin{array}{l}\text { Experientia } \\
1 \\
\text { correlation }\end{array}$ & $\begin{array}{l}\text { Learning } \\
\text { process is } \\
\text { parochial/exam } \\
\text { s do not assess } \\
\text { skills or } \\
\text { aptitude. }\end{array}$ \\
\hline 3. & 2011 & $\begin{array}{l}\text { Double- } \\
\text { scope } \\
\text { network }\end{array}$ & $\begin{array}{l}\text { Input space } \\
1 \text { : verbal } \\
\text { (caption) } \\
\text { Input space } \\
\text { 2: Visual }\end{array}$ & $\begin{array}{l}\text { Experientia } \\
1 \\
\text { correlation }\end{array}$ & $\begin{array}{l}\text { Education } \\
\text { policies do not } \\
\text { build a } \\
\text { competent } \\
\text { human being / } \\
\text { learner. }\end{array}$ \\
\hline 4. & 2011 & $\begin{array}{l}\text { Double- } \\
\text { scope } \\
\text { network }\end{array}$ & $\begin{array}{l}\text { Input space } \\
\text { 1: verbal } \\
\text { (caption) \& } \\
\text { visual } \\
\text { Input space } \\
\text { 2: Visual }\end{array}$ & $\begin{array}{l}\text { Analogical } \\
\text { mapping }\end{array}$ & $\begin{array}{l}\text { Teaching is } \\
\text { destructive } \\
\text { rather than } \\
\text { constructive. }\end{array}$ \\
\hline
\end{tabular}




\begin{tabular}{|c|c|c|c|c|c|}
\hline 5. & 2010 & $\begin{array}{l}\text { Double- } \\
\text { scope } \\
\text { network }\end{array}$ & $\begin{array}{l}\text { Input space } \\
\text { 1: verbal } \\
\text { (inscription) } \\
\text { Input space } \\
2: \text { Visual. } \\
\text { Caption } \\
\text { provides } \\
\text { contextual } \\
\text { cues to } \\
\text { construe } \\
\text { metaphoric } \\
\text { cartoon }\end{array}$ & $\begin{array}{l}\text { Analogical } \\
\text { mapping }\end{array}$ & $\begin{array}{l}\text { High } \\
\text { enrollment \& } \\
\text { alarming } \\
\text { number of } \\
\text { grads inundate } \\
\text { the labour } \\
\text { market causing } \\
\text { unemployment } \\
\text { Faculties } \\
\text { supply more } \\
\text { grads than the } \\
\text { market } \\
\text { demands. }\end{array}$ \\
\hline
\end{tabular}

It is evident that the double-scope network is the prevailing type in the five cartoons; double-scope networks triggered metaphorical blends. The meaning constructed via blending centered on the abstract concept 'education' or any metonymical representation in the five cartoons. The analysis yields the finding that the cartoonist deploys the visual and verbal modes, where the verbal mode anchors the meaning to the visual mode. Both modes act as input spaces in the double-scope conceptual networks. It is worth noting that cartoons 2, 4, and 5 activate cultural models entrenched in the Egyptian society, whereby answering exams is rendered as a process of spouting stored information; the teaching process is physical abuse; and massive numbers of university graduates are in vain pumped into the labour market.

The use of blending in the five cartoons accounts for the processes of dynamic meaning construction. The abstract concept of education and any metonymic representation of the concept are visually realized in the cartoons via metaphor. The cartoonist ingeniously blends the verbal (i.e., captions and inscription) and visual (i.e., images) modes to create meanings and convey messages. The features of metaphoric blends specified by Grady (2005) are evident in three cartoons 1-3. The metaphoric blends are based on correlations in experience; the metaphoric blend in cartoons 4 and 5 is based on analogical associations between concepts. The analysis equally focuses upon the novel inferences and conceptualizations that arise from such metaphoric blends. It is evident that physical punishment, memorizing, incompetency, and lack of 
creative thinking are connotations associated with the education system in Egypt. The cartoons represent highly creative blending processes.

Moreover, the cartoonist could steer the viewers' interpretation of the ideologically loaded cartoon towards ridiculing the current education system. Cartoon 1 delivers the message that education system needs corrective measures and effective strategies. Cartoon 2 hints that curricula must be modified; exams must assess creative and critical thinking rather than memorizing; the learning process needs an upsurge. Cartoon 3 conveys the message that education strategies do not build a competent learner or even a human being. Cartoon 4 defines the teaching process as physical abuse and psychological destruction. Cartoon 5 conveys the message that the education strategies even at the university level need amendment, as the enrollment is high and the graduates are not qualified to meet the requirements of the labour market. The cartoonist arouses the reader's/viewer's feelings of anger towards the students' physical abuse, empathy and sorrow over the current status of education. Consequently, the readers are induced to unravel the implied messages, which prompts for speculations over the current education system.

A final remark is that the cartoonist mainly deploys double-scope integration networks which incorporate two clashing frames. Sometimes, the clash generates humor; however, the cartoonist backgrounds humor and skillfully merges the two input spaces to deliver a certain message, i.e., satirizing the education system in Egypt, which fails to empower students technically and technologically. Finally, since meaning is a negotiable process between the cartoonist and the viewer, rather than a cartoon-inherent quality, as El Refaie (2003) underlies, the five cartoons are open to other possible interpretations and verbalizations; viewers can construct possibly acceptable blends that reflect their own assumptions, experiences, and background knowledge.

\section{Conclusion}

The study highlights how the metaphoric blends in cartoons serve to construct meaning and to address the viewer's emotions and analytical thinking. The double-scope network proves effective in activating metaphoric blends in the five cartoons. Such blends manage to communicate Dr.Sherif Arfa's satirical stance vis-a-vis the current 
education system. His satirical messages prompt for corrective strategies. The visual and the verbal modes act as input spaces, trigger the cognitive processes of constructing metaphoric blends, and shape the ideological meaning of the cartoons. The cartoonist attempts to orient the viewer into a certain position to interpret the implied messages in the five satirical cartoons as a rejection of the current education system.

\section{Acknowledgements}

The researcher is deeply indebted to Prof. Turner, Prof. Fauconnier, Prof. Coulson, and Prof. Oakley for their insightful comments- via emailsconcerning cartoon 2 . The researcher is grateful for the valuable feedback given by Dr. Sherif Arafa-via emails-concerning cartoons 1 and 4. 


\section{References}

Abdel-Raheem, A. (2016). Mostafa Houssein's Satan's family: Conceptual blending in a post-coup Egypt editorial cartoon. Metaphor and the Social World, 6(2), 304325.

Bounegru, L., \& Foceville, C. (2011). Metaphors in editorial cartoons representing the global financial crisis. Visual Communication, 10(2), 209-229. doi: $10.1177 / 1470357211398446$

Coulson, S. (2005). Extemporaneous blending: Conceptual integration in humorous discourse from Talk Radio. Style, 39(2), 107- 121.

Coulson, S. (2006). Conceptual blending in thought, rhetoric, and ideology. In G. Kristianian, M. Achard, R. Dirven, \& F.J.R. Ibanez (Eds.), Cognitive linguistics: Current applications and future perspectives (pp.187-208). Berlin: Mouton de Gruyter.

Coulson, S., \& Matlock,T. (2001). Metaphor and the space structuring model. Metaphor and Symbol, 16 (3\&4). 295-316.

Coulson, S., \& Oakley,T. (2000). Blending basics. Cognitive Linguistics, 11(3-4), 175196.

Coulson, S., \& Oakley,T. (2005). Blending and coded meaning: Literal and figurative meaning in cognitive semantics. Journal of Pragmatics, 37, 1510-1536.

Croft, W., \& Cruse, D.A. (2004). Cognitive linguistics. Cambridge: Cambridge University Press.

Džanić, N., D., \& Omazić, M. (2011). Conceptual blending in political cartoons. In N. Tomović \& J. Vujić (Eds.), ELLSIIR Proceedings of International conference to mark the $80^{\text {th }}$ Anniversary of the English Department: English Language and Literature Studies: Image, Identity, Reality (pp.51-64). Belgrade: Faculty of philology, University of Belgrade.

El -Arousy, N. (2016). Towards a cognitive semiotic analysis of Egyptian cartoon. In L. A. Youssef \& S.A. Kamel (Eds.) Proceedings of the $12^{\text {th }}$ international symposium on comparative literature: Language and Literature of Resistance (pp. 397-416). Cairo: The Department of English Language and Literature, Faulty of Arts, Cairo University.

El Refaie, E. (2003). Understanding visual metaphor: The example of newspaper cartoons. Visual Communication, 2(1), 75-95.

El Refaie, E. (2009). Multiliteracies: How readers interpret political cartoons. Visual Communication. 8(2), 181-205.

El Refaie, E., \& Hörschelmann, K. (2010). Young people's readings of a political cartoon and the concept of multimodal literacy, Discourse: Studies in the Cultural Politics of Education, 31(2), 195-207. doi: 10.1080/01596301003679719.

Evans, V., \& Green, M. (2006). Cognitive linguistics: An introduction. Edinburgh: Edinburgh University Press Ltd.

Fludernik, M. (2015). Blending in cartoons: The production of comedy. In L. Zunshine (Ed.) , The Oxford handbook of cognitive literary studies (pp.155-175). Retrieved July 10, 2017, from http:// books. google. com. eg/books/. 
Fauconnier, G., \& Turner, M. (1998). Conceptual integration networks. Cognitive Science, 22(2), 133-187.

Fauconnier, G., \& Turner, M. (2002). The way we think: Conceptual blending and the mind's hidden complexities. New York: Basic Books.

Forceville, C. (2016). Conceptual metaphor theory, blending theory and other cognitivist perspectives on comics. In N. Cohen (Ed.), The visual narrative reader (pp.89114). Retrieved July 10, 2017, from http://books.google.com.eg/books/.

Grady, J. (2005). Primary metaphors as inputs to conceptual integration. Journal of Pragmatics, 37, 1595-1614.

Grady, J., Oakley, T., \& Coulson, S. (2007). Blending and metaphor. In V. Evans, B. K. Bergen \& J. Zinken (Eds.), The cognitive linguistics reader (pp 420-440). London: Equinox. Previously published (1999) in R. Gibbs, \&, G. Steen (Eds.), Metaphor in cognitive linguistics (pp. 101-124). Amsterdam/Philadelphia: John Benjamins.

Hart, C. (2016). Discourse grammar and ideology: Functional and cognitive perspectives. London: Bloomsbury Academic.

Joy, A., Sherry, J., \& Deschenes, J. (2009). Conceptual blending in advertising. Journal of Business Research, 62, 39-49.

Kok, S., \& Bublitz, W. (2011). Conceptual blending, evaluation and common ground: George W. Bush and Saddam as friend or foe? In S. Handl \& H-J. Schmid (Eds.), Windows to the mind (291-309). Berlin: Walter de Gruyter Gmb H\&Co.

Lakoff, G., \& Johnson, M. (1980). Metaphors we live by. Chicago: University of Chicago Press.

Li, M., \& Gao, Y. (2011). An analysis of internet catchwords from the perspective of conceptual blending theory. Theory and Practice in Language Studies,1(6), 635-643.

Turner, M. (2006). Compression and representation. Language and Literature, 15(1), 17-27.

Yongxiang, Y. (2015). The explanatory power of conceptual integration theory for English proverbs. Studies in literature and language, 11(3), 52-56. doi: 103968/7513

Websites

http://drsherif.net, accessed 10 May 2016

Metaphoric Blends in Online Cartoons on Egypt's Education System

الخلط المجازي فى الرسومات الكاريكاتورية المنشورة علي الإنترنت عن التعليم في مصر 
